\title{
熱処理した鋼のX線による残留応力の測定についで*
}

\author{
本山盛太郎** 米谷茂 ${ }^{* *}$ 堀 沢 寛**
}

\section{On the Measurement of Residual Stress in Heat Treated Steel by X-Ray Method}

by

\author{
Moritaro Motoyama,
}

(Engineering Laboratory, Nissan Motor Co., Ltd., Yokosuka)

\section{Shigeru YONETANI}

(Training Institute for Engineering Teachers of Yokohama National University, Yokohama) and Hiroshi HorizAwA

(Engineering Laboratory, Nissan Motor Co., Ltd., Yokosuka)

\begin{abstract}
On the measurement of residual stress in the quenched steel and in the tempered steel, comparative studies have been made both of the X-ray method and the mechaincal method, differing in the measurement procedure and in the principle, and their results have respectively been investigated. After the plates or the cylinders were removed in succession from the outer layer, the resultant strain has been calculated from the surface residual stress measured by the X-ray method in the remaining part during the removal process. Then it is compared with the bulk strain obtained by the measurement of the residual stress made by the mechanical method.

(Received Aug. 2, 1968)
\end{abstract}

\section{1 緒言}

普通残留応力を求めるには, 試料の一部を除去して 残った部分の変形を測定して機械的に残留応力を求め る. X線的方法では除去後残った部分の表面の残留応 力を測定して, これより試料内部の残留応力を求める ことが行なわれる.このようにX線的方法と機械的方 法については，测定操作上，また原理上その測定方法 は異なる、本報告に打いては，焼入れ，あるいは焼も どしをした円筒および板について，実用的な意味を兼 ねて各条件数個の試料を用いて，これらの残留応力を X線的な Schaal 法, 拈よび機械的な方法で測定を行 ない，両者の結果を比較検討したものである.

X線による残留応力の測定は, 回折に寄与する特定 の結晶面の格子ひずみの測定に帰着するわけであるが， 回折線の移動に影響するものは, 格子面間の一様なひ ずみのほかに, 焼入れ拈よび暁もどしをして変態や, それに伴ら大きな塑性変形を経過した試料については, 積層欠陥の存在, 粒間応力, 相応力などの微視的な応 力による影響も考えられて，この測定結果は試料全体 の巨視的な尺度で機械的に測定された結果といくぶん

* 原稿受理 昭和 43 年 8 月 2 日

** 正会員 日産自動車(株)研究所 横須賀市夏島町

*** 正会員 横㑟国立大学工業教員養成所 横兵市南区大岡町
異なる結果が予想される．また，残留応力を求める際， 回折線の移動に弾性定数を含む定数を乗じて応力を計 算するが，この弾性定数の正確な決定には $\operatorname{Sin}^{2} \psi$ 法を 用いて決定することが行なわれている．本実験におい ては，Schaal 法を用いているが，機械的測定による 結果との比較に際して, 弾性定数を乗じて求める応力 の比較を行なわず， Schaal 法によって得られた表面 主応力方向の 2 万向より入射して撮影した回折線のず れより，応力状態を平面応力と仮定して，これより主 応力方向の応力に対応する格子ひずみを求め, これと 機械的測定によるひずみを対応させて残留応力の測定 結果について検討をした。

\section{2 実 験 方 法}

X線による応力測定にはザイフェルト社のェレスコ ープを用い写真法によった。本山らはさきに，この装 置によって Schaal 法による残留応力測定について改 良や精度などについて検討した結果を報告した，本実 験は同様に行なったもので試験条件を略記すると，特 性 $\mathrm{X}$ 線: $\mathrm{CrK} \alpha$, 照射面積 : $4.5 \mathrm{~mm} \times 3 \mathrm{~mm}$, フィル ム: サクラ $\mathrm{N}$ タイプ, 管電圧および電流 : $40 \mathrm{kV}-10$ 〜 $12 \mathrm{mmA}$, フィルタ : Vフィルタである.

次に, Schaal 法によって表面の主応力方向の格子 ひずみを求める式を示す. Schaal 法は試料面法線よ 
り $45^{\circ}$ 傾いた方向よりX線を照射して，回折写真のず れを求めこれから応力を得るものであるが，いまずれ を $\Delta$, 回折角を $\theta, \eta=90^{\circ}-\theta$ として試料の表面法線 より $45^{\circ}+\eta, 45^{\circ}$ ー 傾いた方向の格子面間のひずみ を $\varepsilon_{45+\eta}, \varepsilon_{45-\eta}$, 試料とフィルムの距離をRとすると

$$
\varepsilon_{45-\eta}-\varepsilon_{45+\eta}=\frac{\tan \eta \cos ^{2} 2 \eta}{2 R} \Delta
$$

の関係がある. 次に Fig. 1 に示すように主応力方向 1.2 について Schaal 法によるずれを $\Delta_{1}, \Delta_{2}$ とし， このとき 1.2 方向の応力㧊よびひずみを $\sigma_{1}, \sigma_{2}, \varepsilon_{1}$, $\varepsilon_{2}$ とすると, 図示の任意の方向のひずみ $\varepsilon_{\varphi, \phi}$ は

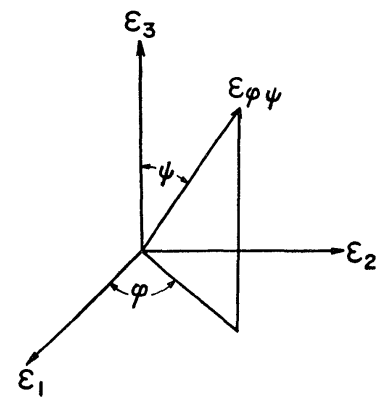

Fig. 1. Principal_strain $\varepsilon_{1}, \varepsilon_{2}$ in surface and strain $\varepsilon_{\varphi, \psi}$ at arbitrary direction.

$$
\varepsilon_{\varphi, \psi}=\left(\varepsilon_{1} \cos ^{2} \varphi+\varepsilon_{2} \sin ^{2} \varphi\right) \sin ^{2} \psi+\varepsilon_{3} \cos ^{2} \psi
$$

の関係がある. $\varphi=0, \quad \psi=45^{\circ}+\eta, \quad \psi=45^{\circ}-\eta$, およ び $\varphi=90^{\circ}, \psi=45^{\circ}+\eta, 45^{\circ}-\eta$ の各場合を(2)式に代 入すると

$$
\begin{aligned}
& \varepsilon_{1}-\varepsilon_{3}=\left(\varepsilon_{1}, 45+\eta\right. \\
& \left.\varepsilon_{2}-\varepsilon_{1,45-\eta}\right) \frac{1}{\sin 2 \eta} \\
& =\left(\varepsilon_{2}, 45+\eta\right. \\
& \left.-\varepsilon_{2,45+\eta}\right) \frac{1}{\sin 2 \eta}
\end{aligned}
$$

を得る。また(1)式より

$$
\left.\begin{array}{l}
\varepsilon_{1}, 45-\eta-\varepsilon_{1},{ }_{45+\eta}=\frac{\tan \eta \cos ^{2} 2 \eta}{2 R} \Delta_{1} \\
\varepsilon_{2}, 45-\eta-\varepsilon_{2},{ }_{45+\eta}=\frac{\tan \eta \cos ^{2} 2 \eta}{2 R} \Delta_{2}
\end{array}\right\}
$$

の関係がある. 平面応力状態とすると応力とひずみの 関係より

$$
\varepsilon_{3}+\frac{\nu}{1-\nu}\left(\varepsilon_{1}+\varepsilon_{2}\right)=0
$$

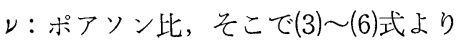

$$
\begin{aligned}
& \varepsilon_{1}=-\frac{1}{1+\nu} \frac{\cos ^{2} 2 \eta}{4 R \cos ^{2} \eta}\left(\Delta_{1}-\nu \Delta_{2}\right) \\
& \varepsilon_{2}=-\frac{1}{1+\nu} \frac{\cos ^{2} 2 \eta}{4 R \cos ^{2} \eta}\left(\Delta_{2}-\nu \Delta_{1}\right)
\end{aligned}
$$

上式より，表面応力方 1.2 のひずみが得られる。 たヤング率をEとし，応力とひずみの関係を用いると

$$
\sigma_{1}=-\frac{E}{1+\nu} \frac{\cos ^{2} 2 \eta}{4 R \cos ^{2} \eta} \Delta_{1}
$$

$$
\sigma_{2}=-\frac{E}{1+\nu} \frac{\cos ^{2} 2 \eta}{4 R \cos ^{2} \eta} \Delta_{2}
$$

が得られる．実験に際してはRは常に $50 \mathrm{~mm}$ になる ようにし， $=0.28$ として試料の（211）面間のひず みを求めた。 また応力を求めるときは $E=21000 \mathrm{~kg} /$ $\mathrm{mm}^{2}$ とした.

実験は，まず，Fig. 2 に示すよらな $0.4 \% \mathrm{C}$ の中空 円筒を数個油焼入れおよび水焼入れをし，この試料を 硝酸によって内層の逐次除去をし，X線的測定のとき は, 試料外表の特定の対称 2 点について, Schaal法に よる軸方向, 抢よび円周方向の回折線のずれを測定し て(7)式より軸方向の残留ひずみを求め，また，機珹的 には内層除去による軸方向の長さを測定した。これら より内層除去によって得られる軸方向のX線的ひずみ の変化と機械的ひずみの一致を検討した。

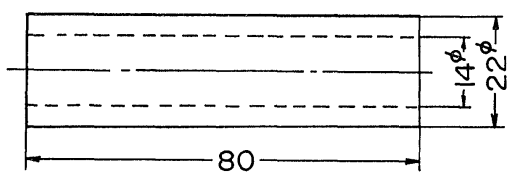

Fig 2. Size of hollow cylinder specimen.

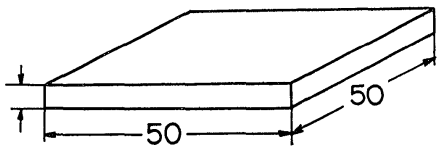

F1g. 3. Size of plate specimen.

次に, Fig. 3 に示す $0.4 \% \mathrm{C}$ の数個の板を水焼入れ をし，板の上下面を逐次腐食除去をし，板の上下の対 称な点について, 除去過程中の表面の残留ひずみを測 定し, これより次に述べる式によって除去に伴ら長手 方向のひずみを計算し，これと機械的方法による実測 結果と比較検討した。

外表除去過程中の試料のX線的な表面ひずみより， 板の除去に伴ら長手方向のひずみを求める式を述べる. 板の厚さを $2 z_{0}$ とする. 板の長手方向の残留応力を ${ }_{0} \sigma_{x},{ }_{0} \sigma_{y}$ とする. これは中央面に対称で厚さのみの関 数とする。いま両面より除去をして厚さ $2 z$ になった とする.このときの板の表面の残留応力を ${ }_{0} \sigma_{x}{ }^{\prime},{ }_{0} \sigma_{y}{ }^{\prime}$ とする、いま焼入れの場合であるから ${ }_{0} \sigma_{x}={ }_{0} \sigma_{y},{ }_{0} \sigma_{x}^{\prime}$ $={ }_{0} \sigma_{y}{ }^{\prime}$ と考える. すると次のつりあい式が成立する.

$$
{ }_{0} \sigma_{x}^{\prime}={ }_{0} \sigma_{x}+\frac{1}{z} \int_{z}^{z_{0}}{ }_{0} \sigma_{x} d z
$$

両辺にzをかけ，次いでこれを微分すると

$$
\frac{d_{0} \sigma_{x}}{d z}=\frac{{ }_{0} \sigma_{x}^{\prime}}{z}+\frac{d_{0} \sigma_{x}{ }^{\prime}}{d z}
$$

これをzより $z_{0}$ まで積分すると， ${ }_{0} \sigma_{x}\left(z_{0}\right)={ }_{0} \sigma_{x}{ }^{\prime}\left(z_{0}\right)$ であり 


$$
{ }_{0} \sigma_{x}={ }_{0} \sigma_{x}{ }^{\prime}-\int_{z}^{z_{0}} \frac{0_{0} x^{\prime}}{z} d z
$$

また，板を $2 z$ まで外層除去したとき，残った部分に 一様に付加する伈力を $\sigma_{x}$ とすると

$$
\int_{z}^{z_{0}} 0^{\sigma_{x}} d z=z \sigma_{x}
$$

である. (13)式に(12)式を代入し， $0^{\sigma}{ }^{\prime} ， \sigma_{x}$ に対応するひ ずみを $\varepsilon_{0}{ }^{\prime}, \varepsilon_{x}$ として応力とひずみの関係

$$
\begin{gathered}
{ }_{0} \varepsilon_{x}{ }^{\prime}=\frac{1}{E}\left({ }_{0} \sigma_{x}{ }^{\prime}-\nu_{0} \sigma_{y}{ }^{\prime}\right)=\frac{1}{E}(1-\nu)_{0} \sigma_{x}{ }^{\prime} \\
\varepsilon_{x}=\frac{1}{E}(1-\nu) \sigma_{x}
\end{gathered}
$$

を用いると

$$
\varepsilon_{x}=\int_{z}^{z_{0} \varepsilon_{x}^{\prime}} \frac{\varepsilon_{x}}{z} d z
$$

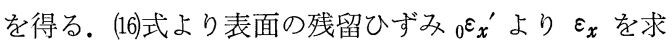
め, 機械的測定による $\varepsilon_{x}$ と比較できる.

次に，中実円筒について，板の場合と同様な実験 を行なった。中実円筒として，試料組成 $0.4 \% \mathrm{C}$ の Fig. 4 に示す $11.3 \mathrm{~mm} \phi$ 長さ $80 \mathrm{~mm}$ のものを水焼 れをし，これを $100 ， 200 ， 300 ， 400^{\circ} \mathrm{C}$ の各温度に焼 もどしをした. 各条件数個の試料を熱処理をし，これ らについて外層より逐次除去を行ない， $\mathrm{X}$ 線的には Schaal 法で除去過程中の試料表面の対称な 2 点につ いての平均の軸方向, 円周方向の残留ひずみを求め, これより次に示す式によって，除去によってもたらさ れる軸方向のひずみを計算し，これと機械的測定によ るひずみとの比較を行なった。

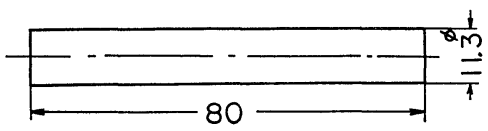

Fig. 4. Size of solid cylinder specimen.

除去過程中の試料の表面の軸方向, 沶よび円周方向 の残留ひずみ $0_{0} z^{\prime},{ }_{0} \varepsilon_{t}^{\prime}$ より軸方向のひずみ $\varepsilon_{z}$ を求 める式を示す. 円筒は軸方向, 円周方向および半径方 向に ${ }_{0}{ }_{z},{ }_{0} \sigma_{t}, 0_{0}{ }_{r}$ なる残留応力をもち, これらの応 力は半径 $r$ の関数であるとする. そして軸方向に試料 は充分長いとする，いま，試料を半径 $r_{0}$ から $r$ まで 除去したとする。このとき残った円筒に除去によって 一様な応力が付加するとする，するとこの円筒の外表 部の軸方向および円周方向の残留応力を ${ }_{0} \sigma_{z}{ }^{\prime},{ }_{0} \sigma_{t}{ }^{\prime}$ と すると, 軸方向の力のつりあい式として次の式が成立 する。

$$
{ }_{0} \sigma_{z}{ }^{\prime}(r) \pi r^{2}={ }_{0} \sigma_{z}(r) \pi r^{2}+\int_{r}^{r_{0}} 2_{0} \sigma_{z} \pi r d r
$$

(17)式を微分すると

$$
\frac{d_{0} \sigma_{z}}{d r}=2 \frac{{ }^{0} \sigma_{z}^{\prime}}{r}+\frac{d_{0} \sigma_{z}^{\prime}}{d r}
$$

昭和 43 年 12 月
上式を $r$ より $r_{0}$ まで積分すると， ${ }_{0} \sigma_{z}\left(r_{0}\right)={ }_{0} \sigma_{z}{ }^{\prime}(r)$ であるから

$$
{ }_{0} \sigma_{z}=-2 \int_{r}^{r_{0}{ }_{0} \sigma_{z}^{\prime}} \frac{}{r} d r+{ }_{0} \sigma_{z}{ }^{\prime}
$$

また, 半径 $r$ までの除去で, 半径 $r$ の部分に和ける半 径方向の残留応力 ${ }_{0} \sigma_{r}(r)$ が解放されるから, 結果と して半径 $r$ の円筒に ${ }_{0}{ }_{r}(r)$ なる外圧が加わることに なる、すると Lamé の円筒理論から,

$$
{ }_{0} \sigma_{t}{ }^{\prime}(r)={ }_{0} \sigma_{t}(r)-{ }_{0} \sigma_{r}(r)
$$

円周方向と半径方向の応力のつりあい式は

$$
{ }_{0} \sigma_{t}=r \frac{d_{0} \sigma_{r}}{d r}+{ }_{0} \sigma_{r}
$$

であるから，(20)式を(19)式に代入すると

$$
\frac{d_{0} \sigma_{r}}{d r}=\frac{{ }_{0} \sigma_{t}^{\prime}}{r}
$$

上式を積分して， ${ }_{0} \sigma_{r}\left(r_{0}\right)=0$ であるから

$$
{ }_{0} \sigma_{r}=-\int_{r}^{r_{0}} \frac{\sigma_{t} \sigma_{t}^{\prime}}{r} d r
$$

(21)式を(20)式に代入すると

$$
{ }_{0} \sigma_{t}=-\int_{r}^{r_{0}{ }_{0} \sigma_{t}{ }^{\prime}}{ }_{r} d r+{ }_{0} \sigma_{t}{ }^{\prime}
$$

また，半径 $r_{0}$ より $r$ までの除去によって残った円筒 に生ずる軸方向のひずみ $\varepsilon_{z}$ は

$$
\varepsilon_{z}=2 \nu \frac{{ }_{0} \sigma_{r}}{E}+\frac{1}{\pi r^{2} E} \int_{r}^{r_{0}} 2 \pi r_{0} \sigma_{z} d r
$$

の関係がある。(23)式に(18)，(20)式を代入し，応力とひず 久の関係

$$
\begin{aligned}
& { }_{0} \sigma_{z}{ }^{\prime}=\frac{E}{1+\nu}\left\{{ }_{0} \varepsilon_{z}{ }^{\prime}+\frac{\nu}{1-\nu}\left({ }_{0} \varepsilon_{z}{ }^{\prime}+{ }_{0} \varepsilon_{t}{ }^{\prime}\right)\right\} \\
& { }_{0} \sigma_{t}^{\prime}=\frac{E}{1+\nu}\left\{{ }_{0} \varepsilon_{t}{ }^{\prime}+\frac{\nu}{1-\nu}\left({ }_{0} \varepsilon_{t}{ }^{\prime}+{ }_{0} \varepsilon_{z}{ }^{\prime}\right)\right\}
\end{aligned}
$$

を用いると次の式を得る。

$$
\varepsilon_{z}=2 \int_{r}^{r_{0}{ }_{0} \varepsilon_{z}{ }^{\prime}} \frac{}{r} d r
$$

したがって，(26) 式より X線的残留ひずみ ${ }_{0} \varepsilon_{z}{ }^{\prime}$ から $\varepsilon_{z}$ を計算して，機械的測定による $\varepsilon_{z}$ と比較できる。 た，各熱処理のものについて，各条件 2 個の試料につ いて，(9)，(10)式の関係から直接応力を求め，(18)，(21), (22)式を用いて残留応力分布を計算した。

\section{3 実 験 結 果}

\section{$3 \cdot 1$ 中空円筒に関する実験}

この実験は残留応力をもつ部材について，その一部 を逐次除去したとき，残った部分に付加する弾性ひず みをX線的方法と機械的方法によって比較したもので ある.Fig. 5，6 に水焼入れ，抢よび油焼入れをした ものについて, 内層除去に伴ら外表中央部分に和ける X線的残留ひずみを(7), (8)式より求めた結果と, 試料 全体について機械的に测定した軸方向のひずみを示し てある.X線的測定および機械的測定はそれぞれ 2 個および 3 個の試料について測定した。図中横軸は除 


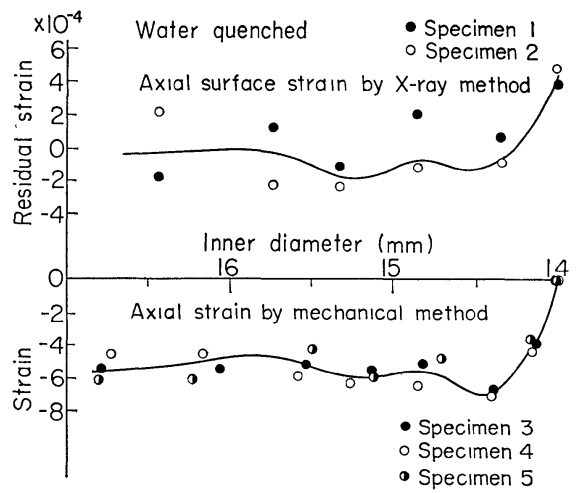

Fig. 5. Axial residual strain by $\mathrm{X}$-ray method at the outer surface of cylinder and mechanical axial strain resulted by successive removal of inner layer on water quenched specimens.

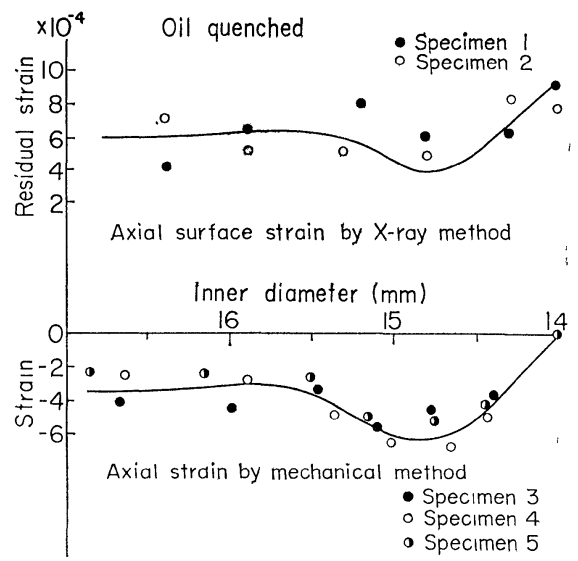

Fig 6. Axial residual strain by $\mathrm{X}$-ray method at the outer surface of cylinder and mechanical axial strain resulted by successive removal of inner layer on oil quenched specimens.

去中の試料内径である.

円筒は内層の除去によって残った部分に一様に軸方 向の変形が現わ机るわけであるが，水燒れ，油焼入れ いずれの場合も，X線的ひずみの変化と，機械的測定 によるひずみはほぼー致する．X線的ひずみは試料外 表の特定の部分についての局所的な小領域における格 子面間距離の移動によるものであり，このため機械的 ひずみの測定結果に比べていくぶん分散を示すことは 避られない。このように内層除去によって付加する X 線的ひずみと機械的ひずみの一致は，さきに示した板 拉よび円筒の残留応力分布を求める式に拈いて，外層 除去によって試料内に応力ないしひずみが一様に付加 すると仮定したが，この結果から(12)あるいは(18)，(21)， (22)式より残留応力分布を求めらることがわかる.

\section{$3 \cdot 2$ 平板に関する実験}

板を水焼入れしたときは, 残留応力分布は板内一様 で厚さのみの関数で最も単純な分布を示す。 Fig. 7

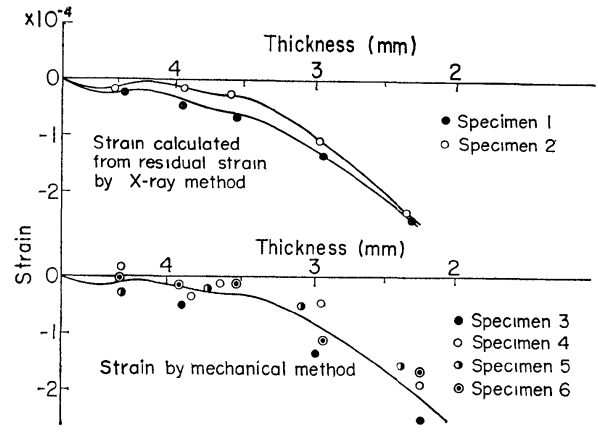

Fig. 7. Strain intransversal direction resulted by successive removal of outer layer on water quenched plate specimens.

に 2 個の試料について，板の上下面を除去したときの 板の表面の X線的残留ひずみから，(16)式より板の長手 方向の除去に伴って現われるひずみ $\varepsilon_{x}$ を計算した結 果と， 4 個の試料について機珹的方法によるひずみ $\varepsilon_{x}$ を示す。試料間のばらつきや焼入時の不同性を考虑し ても，両者の結果はよく一致することがわかる.

\section{$3 \cdot 3$ 中実円筒に関する実験}

水焼入れ，および $100 ， 200 ， 300 ， 400^{\circ} \mathrm{C}$ 燒もどし をした各条件 2 個の試料について，外層除去過程中の 試料のX線的表面残留ひずみより，(26)式を用いて外層 除去に伴う軸ひず为 $\varepsilon_{z}$ を計算した結果と，また同一 条件 3 個の試料について機械的な軸ひずみを測定した 結果を Fig. 8 に示す. また, Schaal 法より直接 $E$ $=21000 \mathrm{~kg} / \mathrm{mm}^{2}$ として(9), (10)式から表面残留応力を 求め，(18)，(21)，(23)式より 2 個の試料について残留応力 分布を計算した結果をFig. 9 に示す。

各条件のものについてX線的に求めた軸ひずみと, 機械的測定による軸ひずみとの対応を説明する。 まず, 燒入れのままのるのは，Fig. 9 に示すように，残留 応力は三軸応力状態であって, 軸方向と円周方向の応 力は大きく，それぞれ異なった分布であって板のよう に単純ではない，この場合軸ひずみの対応は，機械的 測定によるものは，外層除去の初期にやや大きなひず みが現われているが，全体として両者のひずみはほほほ 一致する。

$100,200^{\circ} \mathrm{C}$ 焼もどしのものは, Fig. 9 の残留応力 分布において，2 個の試料の残留応力は同じ傾向の分 布であるがいくぶん差のある分布を示している．Fig. 8 の軸ひずみに预いても，2 個の試料のX線的軸ひず み曲線は焼入れのものに比べてやや分離している。李 た，機械的ひずみとの対応においては，除去に伴うひ ずみ曲線の変化の傾向は同じであるが，最終的にひず みの大きさが異なっている。この場合, 組織としては, 焼もとしによって全体としての残留応力の緩和はある が，組織的に，マルテンサイトマトリックスより微細 


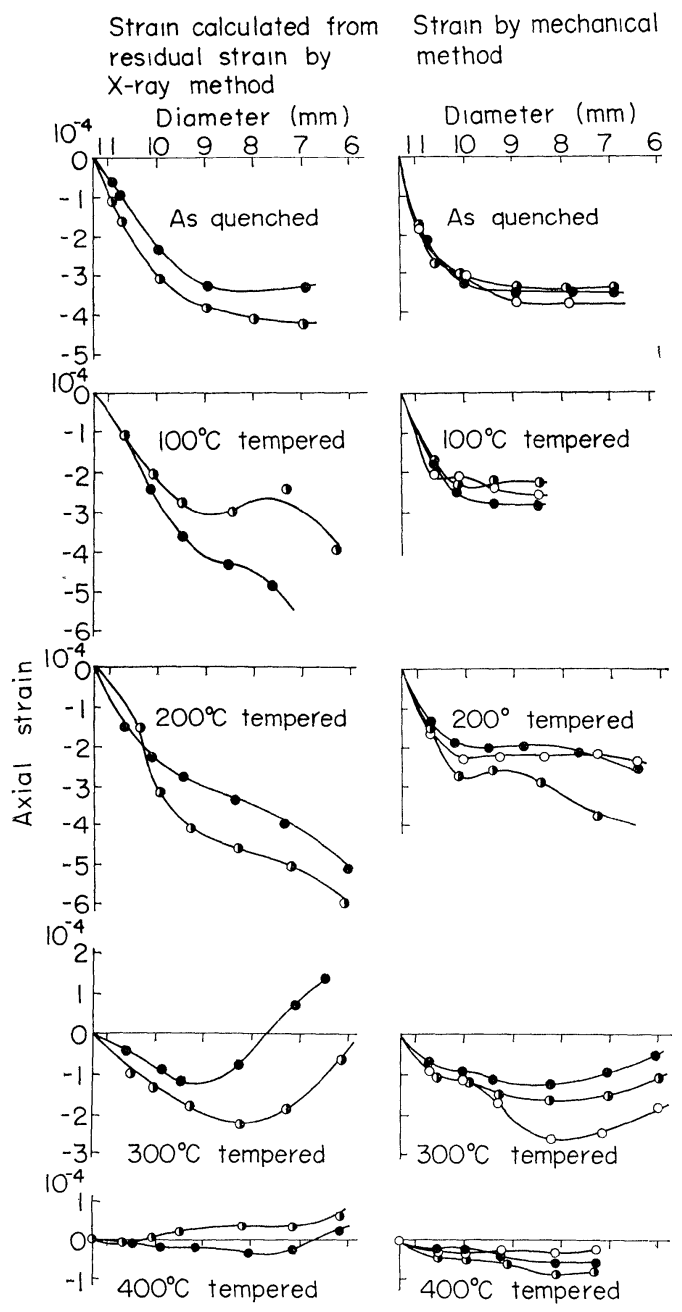

Fig. 8. Axial strain resulted by successive removal of outer layer on the quenched and tempered cylinder specimens.

なと炭化物の析出，さらに $200^{\circ} \mathrm{C}$ 焼もどしのものにな ると, マルテンサイトは C \%濃度の低いマルテンサイ トに移行するなどのことがあって，X線的応力測定に 際して，格子面間距離の移動に基づく巨視的な応力の ほかに，粒間応力などの微視的応力による影響も考え られる場合である．X線的測定による 2 本の試料の結 果の分散は, 焼入れに巨視的残留応力の不一致に, さ らに焼もどしによるこのような組織的な影響が加算し た結果によるものであろら。なお，このとき，除去最 終時のひずみの值は機械的測定とX線的結果で異なっ ているが，いま，(26) 式を微分すると, $r\left(d \varepsilon_{z} / d r\right)=-$ $2_{0} \varepsilon_{z}{ }^{\prime}$ の関係があるから, 試料内各部について両方法 による $\varepsilon_{0} \varepsilon_{z}^{\prime}$ 比較すると, これは軸ひずみ曲線 $\varepsilon_{z}$ の こう配によって決まるものであるから(26)式による結果 とまた異なり，これより両方法による結果の別な検討
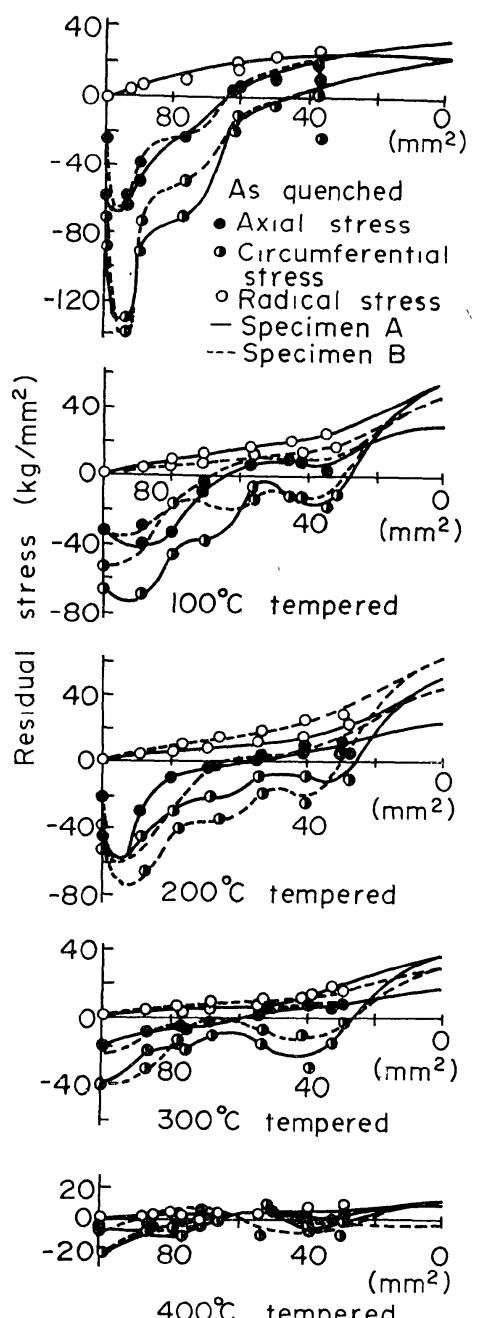

Fig. 9. Residual stress distribution in the quenched and tempered specimens.

ができると思われる。よって両方法による軸ひずみ $\varepsilon_{z}$ の曲線において $\varepsilon_{z}$ の值ばかりでなく，曲線のこら配 の一致も重要である.

次に $300,400^{\circ} \mathrm{C}$ 焼もどしの場合は, Fig. 10 に示す ように，残留応力は焼もどしによって減少しているが， 組織的にはセメンタイトの析出, マルテンサイトのフ ェライトへの分解などがあり，この場合も X線的測定 に際して微視的応力の影響が考兄られる場合である. $300^{\circ} \mathrm{C}$ 焼もどしのときは，2本の試料によるX線的測 定の軸ひずみは小径のところで大きく分離しておら， また機械的測定による 3 本の試料の軸ひずみ曲線はい くぶん差があるが，それぞれについて平均の軸ひずみ 曲線を考えると両者の結果は一致するようである。さ らに，焼もどし段階の進んだ $400^{\circ} \mathrm{C}$ 焼もどしのものは， 同じく両方法による各試料の軸ひずみ曲線はいくぶん 分散を示す。また, その対応性としては, 除去過程初 
期の径の大きい部分でのひずみの差を調整して考光る と, 以後同一傾向の曲線となるようである。

\section{4 考察および結言}

$0.4 \% \mathrm{C}$ の炭素鋼材の平板および円筒を水焼入机抒 よび烧もどしをした試料について，これらを外層除去 をしたときの弛緩ひずみをX線的な Schaal 法によっ て求め,また機械的な測定を行なって，両方法による 残留応力の測定について比較を行なった.

実験は 1 条件 $2 \sim 3$ 本の試料について行なったが, 実際の比較のためには本来なら 1 本の試料についての 結果の検討が望ましい。しかし, 本実験では原理上, X線による測定のときは, 除去外層の表面の局部のひ ずみの測定であり，そして応力分布を板なら常に中央 面に対称とし，円筒なら軸対称と理想な場合を仮定し て，全体的な变形による機械的ひず夕との対応を求め たものである，したがって，測定対象が焼入後のもの のようにこの理想的状態よりいくぶんの偏差を生じや すいものについては，1個の試料についての結果の比 較より，たと兄試料間のばらつきを考慮しても数個の 試料についての結果の検討を行ならほらがより実用的 飞も有利な結果を得ると思われる。本実験では機械的 測定結果より 2 本の試料のX線的測定結果のほうがば らつきは大きい。これ X線測定結果の活らが試料間 のばらつきとより敏感であるためであろう。

次に, X線的残留応力の測定結果と機械的方法に上 る残留応力の測定結果の比較を行ならとき問題になる ことは，まずX線的湘定の場合のいわゆる回折強度に 及ぼす LPA 因子の影響, Schaal 法之機戌的測定と の精度, 拈よび微視的残留応力の影響である. 各因子 について検討すると，まず LPA 因子による影響とし ては, 本実験の上らな大きな焼入残留応力の值住す る比較を行ならときはさほど影響をもつものとは考兄 られない。また, 測定方法の精度としては, Schaal 法 自体このような大きな残留応力の測定の場合, 回折線 の広がりがあったとしてもかなり精度よく求められ， また機械的測定も方法として試料両端面間の長さを測 定するもので最も平易な操作で測定できて精度は出し やすい。したがって, 最終的に問題になるのは, 微視 的残留応力の影響である。
一般に，焼入れしたものはそのマルテンサイト変態 を経過することによって著しい格子欠陥をもっている。 この程度はC％や，燒入方法の急烈さ炕よって異なる ことはもちろんである。したがって，本実験のように 燒入れの場合 X線的と機械的測定の結果のかなりの一 致は，一般的な結論とは別飞，本実験の上うな $0.4 \%$ C鋼の水焼入れしたものについては, 焼入れによる微 視的応力の影響があるにしても, 雨方法の結果はかな り一致するといらことが言えるようである.

次焼もどしをしたものについては，100，2000焼 もどしのとき, マルテンサイトマトリックス内の微視 的な内部ひずみの回復と微細な $气$ 炭化物の析出がある. この状態は C\%によって影響を受けるものである. 本 実験に現われた雨方法によるかなりの差は，焼入時に 一致した状態から, X線の場合, 微視的な組織の変化 とともに微細に析出した 8 炭化物などによる粒間応力 などからの影響が加わるためこのよらな差が現われた ものと考光られる.したがって, この差もC\%や焼入 方法や, 焼入時の残留応力の状態によって異なるもの となるであろう。

$300,400^{\circ} \mathrm{C}$ 焼もぞしの場合は，一致はいくぶん弱 いが，(26)式を微分して求められる表面残留ひずみ ${ }_{0} \varepsilon_{z}^{\prime}$ について対応性を調べると, 試料各部では両者はかな り一致するのではないかと考䍃られる。この場合地は フェライトであり, 析出物も凝集して粒間応力として 残留応力に影響を及㳯すほどの効果はないと思われる が，組織とは別にこの場合残留応力の值は小さい。こ のためこのような測定方法の場合, 測定方法自体によ る䛊差が結果の信頼度に影響してくるものと思われる。 (昭和43年 7 月18日 第 7 回X線材䉼强度化関するシンポジウム亿て 譵演)

\section{参 考 文 献}

1）西山善次, 清水謙一, 日本金属学会会報，2，153（1963）.

2) Greennough, G B, Proc. Roy. Soc, 197A, 556 (1949).

3) Rermer, L., Z. Metallkunde, 46, 39 (1955).

4）本山盛太郎，榎並豊一郎，堀沢 寛，加藤紀久雄，材料 試験， 11，33 (1962); 材料， 12, 835，882 (1963).

5) 日本材料学会編, “X線応力测定法”（1966）盖賢堂 